\title{
Homage to L. M. Coutinho: fire adaptations in cerrado plants
}

\author{
Juli G. Pausas \\ CIDE-CSI C, Carretera de Naquera Km. 4.5, 46113 Montcada, Valencia, Spain. Email: juli.g.pausas@ext.uv.es
}

Charles Darwin never considered fire as a possible evolutionary force. We have learned a lot since then, and currently there is overwhelming evidence that many plants have adapted to historic fire regimes (Keeley et al. 2011, 2012). However, evolutionary fire ecology is a young discipline that has only recently taken root - especially in Mediterranean ecosystems (He et al. 2012; Keeley et al. 2012; Pausas and Schwilk 2012; Pausas 2015a). An important exception was the work of Professor Coutinho (1934-2016) from the University of Sao Paulo, Brazil, who was discussing fire adaptations in South American savannas (cerrado) during the 1970s (e.g. Coutinho 1976, 1977). At that time, fire was thought to be mostly introduced by humans - in the cerrado and in many ecosystems worldwide. Fire was considered an important factor in determining the structure of vegetation, and it was accepted that many cerrado species resist fire (Eiten 1972); however, few researchers were discussing specific fire adaptations in plants. The few researchers studying fire adaptations were focused on Mediterranean ecosystems (Wells 1969; Mutch 1970) and their work was scarcely recognised during the 1970s. For instance, Axelrod (1973, 1989) and Raven and Axelrod (1978) wrote extensively on the origin of Californian flora and assigned no role to fire in the evolution of this fire-adapted flora (Keeley et al. 2012). Meanwhile, Coutinho had a clearly dynamic view of cerrado vegetation at both ecological and evolutionary scales. $\mathrm{He}$ understood that lightning-generated natural fire regimes could select for adaptive response in plants (Coutinho 1976); and he considered that human fires replaced lightning fires. He also understood the dynamic nature of cerrado mosaics where forest expanded in wet periods and retracted in dry periods with greater fire activity (Coutinho 1976), and thus considered forest and savanna as alternative states in the cerrado (Dantas et al. 2016). In his $\mathrm{PhD}$ (Coutinho 1976), Coutinho performed experimental burns in different seasons in the 'Cerrado de Emas' (Pirassununga, Sao Paulo) and provided relevant and novel information on fire behaviour (Coutinho 1978) and nutrient cycling (Coutinho 1979) for the cerrado. In the latter study, he proposed that despite fires generating a loss of nutrients, a fire interval of three years would maintain an equilibrium between input and output; in fact, he suggested that fire would encourage primary productivity by accelerating nutrient cycling (Coutinho 1976; Pivello and Coutinho 1992). A very important contribution of his $\mathrm{PhD}$ was the study of fire-stimulated flowering in the cerrado - a fire-adaptive trait that is still little studied (Lamont and Downes 2011). He documented that the flowering of most herbaceous and suffruticouse (geoxyle) species of cerrado depends quantitatively or qualitatively on fire (Fig. 1). This suggests that cerrado could be the ecosystem where this trait is most prominent; however, this finding is unknown in the international literature (Lamont and Downes 2011). He performed laboratory experiments that involved burning, cutting, fumigating with smoke and imposing drought and different photoperiods on plants growing in pots (four species). He thus showed that flowering is stimulated by the elimination of the aboveground parts, and not by changes in light, heat or chemical cues. He further demonstrated - in an anatomical study - the transformation of vegetative buds into floral buds a few days after a fire (he termed this process pyromorphogenesis; Coutinho 1976; Coutinho et al. 1982). After his PhD, he described serotiny in some cerrado plants (Coutinho 1977); that is, plants that keep the fruit or infrutescens closed during fire to protect the seeds, and then open them to disperse and recruit post-fire. Serotiny is another fire-adaptive trait that has generally been well studied - mostly in pines in the northern hemisphere (He et al. 2012; Pausas 2015a) and in Proteaceae in the southern hemisphere (Lamont et al. 1991) - but not in

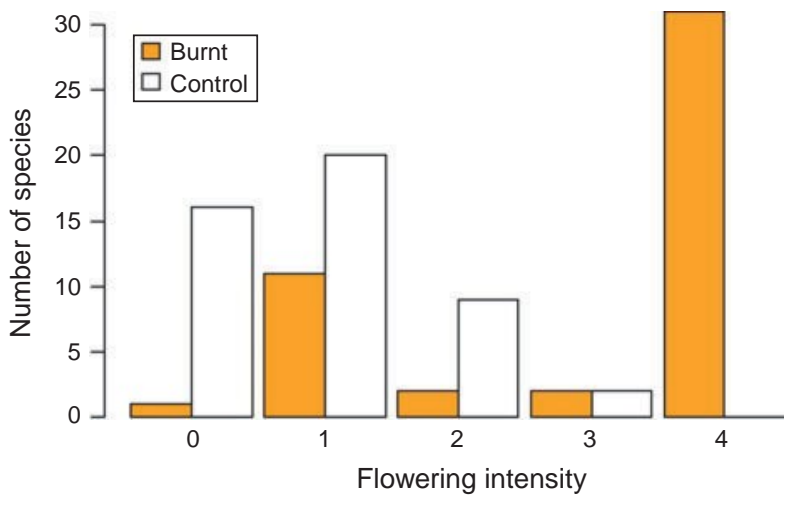

Fig. 1. Frequency distribution of the flowering intensity index (from 0 to 4 ) after fire (shaded; 90 days post-fire) and in control conditions (white) in 47 species (belonging to 20 families) of a cerrado ecosystem (prepared from data in Coutinho 1976). The 31 species with the highest post-fire flowering belong to 17 different families. 
savannas. His pioneering research remains to be examined in more detail and framed with current knowledge; and it should also be evaluated in other savannas worldwide. Coutinho also demonstrated the existence of fire-stimulated germination in Mimosa species from cerrado (Coutinho and Jurkevics 1978); recent studies suggest that there are few other species with firestimulated germination, despite the general response of cerrado plants having seeds tolerant to fire (Ribeiro et al. 2013; Ramos et al. 2016). A few years later, he showed that fire was an old and major factor in the cerrado, by providing evidence of charcoal from cerrado soils dated at 8600 years (Coutinho 1981). Currently, and thanks to phylogenetic techniques, we know that fire may have been an important evolutionary factor in cerrado some 10 million years ago (Simon et al. 2009). Another prominent adaptation of cerrado plants is the very thick and suberised bark for fire protection and epicormic resprouting (Pausas $2015 b$ ). Although he did not make a formal study of this trait, Coutinho specifically noted that the bark was thick in the trunk (as is well known in pines), as well as in lateral branches located 2-3 $\mathrm{m}$ above ground level (i.e., at the top of the flame where fire temperatures can be very high) (Coutinho 1990). This detail has only recently been recognised as a trait differentiating Brazilian cerrado from African savannas (Pausas 2015b, 2017). Similarly, he also suggested that xylopodia could be a response to fire, but that more research was needed (Coutinho 1976); this research has only recently been published (Maurin et al. 2014).

Coutinho was a pioneer of evolutionary fire ecology. He is known among Brazilian researchers for his contributions to cerrado ecology, and because he was professor at one of the major Brazilian universities (University of Sao Paulo). His legacy will remain for future generations, especially thanks to his recent book on Brazilian biomes (Coutinho 2016; published just after his death). However, he is little known elsewhere, perhaps because he was not part of the dominant Anglo-Saxon culture (Amano et al. 2016), but also because he was ahead of his time, when fire and evolution were still distant concepts. Only recently has the evolutionary role of fire in the cerrado been fully recognised (Simon et al. 2009; Dantas and Pausas 2013), supporting his modern view of this emblematic ecosystem that surprised the founders of ecology (Warming 1893).

\section{References}

Amano T, González-Varo JP, Sutherland WJ (2016) Languages are still a major barrier to global science. PLoS Biology 14, e2000933. doi:10.1371/JOURNAL.PBIO.2000933

Axelrod DI (1973) History of the Mediterranean ecosystem in California. In 'Mediterranean ecosystems: origin and structure.' (Eds F di Castri, HA Mooney) pp. 225-277. (Springer-Verlag: New York, NY)

Axelrod DI (1989) Age and origin of chaparral. In 'The California chaparral: paradigms reexamined.' (Ed. SC Keeley) Vol. Science Series No. 34, pp. 7-19. (Natural History Museum of Los Angeles County: Los Angeles, CA)

Coutinho LM (1976) Contribuição ao conhecimento do papel ecológico das queímadas na floraçao de especies do Cerrado. Tese de Livre Docência, Universidade de São Paulo, São Paulo, Brazil.

Coutinho LM (1977) Aspectos ecológicos do fogo no cerrado: II. As queimadas ea dispersao de sementes Boletim de Botanica 5, 57-64.

Coutinho LM (1978) Aspectos ecológicos do fogo no cerrado: I. A temperatura do solo durante as queimadas. Revista Brasileira de Botanica. Brazilian Journal of Botany 1, 93-96.
Coutinho LM (1979) Aspectos ecológicos do fogo no cerrado: III. A precipitação atmosférica de nutrientes minerais. Revista Brasileira de Botanica. Brazilian Journal of Botany 2, 97-101.

Coutinho LM (1981) Aspectos ecológicos do fogo no Cerrado. Nota sobre a ocorrência e datação de carvões encontrados no interior de solo sob Cerrado. Revista Brasileira de Botanica. Brazilian Journal of Botany 4, 115-117.

Coutinho LM (1982) Ecological effects of fire in Brazilian cerrado. In 'Ecology of tropical savannas.' (Ed. GJ Huntley) pp. 273-291. (Springer: Heidelberg, Germany)

Coutinho LM (1990) Fire in the ecology of the Brazilian cerrado. In 'Fire in the tropical biota.' (Ed. J Goldammer) Vol. 84 pp. 82-105. (Springer: Berlin)

Coutinho LM (2016) 'Biomas brasileiros.' (Oficina de Textos: Sao Paulo, Brazil)

Coutinho L, Jurkevics I (1978) Aspectos ecológicos do fogo no cerrado: $\mathrm{V}$. O efeito de altas temperaturas na germinação de uma espécie de Mimosa. Ciencia e Cultura 30(Suppl.), 420.

Coutinho LM, De Vuono YS, Lousa J (1982) Aspectos ecoló gicos do fogo no cerrado: IV. A época da queimada e a produtividade primária líquida epigéia do estrato herbáceo subarbustivo. Revista Brasileira de Botanica. Brazilian Journal of Botany 5, 37-41.

Dantas VL, Pausas JG (2013) The lanky and the corky: fire-escape strategies in savanna woody species. Journal of Ecology 101, 12651272. doi:10.1111/1365-2745.12118

Dantas VL, Hirota M, Oliveira RS, Pausas JG (2016) Disturbance maintains alternative biome states. Ecology Letters 19, 12-19. doi:10.1111/ ELE.12537

Eiten G (1972) The cerrado vegetation of Brazil. Botanical Review 38, 201-341. doi:10.1007/BF02859158

He T, Pausas JG, Belcher CM, Schwilk DW, Lamont BB (2012) Fireadapted traits of Pinus arose in the fiery Cretaceous. New Phytologist 194, 751-759. doi:10.1111/J.1469-8137.2012.04079.X

Keeley JE, Pausas JG, Rundel PW, Bond WJ, Bradstock RA (2011) Fire as an evolutionary pressure shaping plant traits. Trends in Plant Science 16, 406-411. doi:10.1016/J.TPLANTS.2011.04.002

Keeley JE, Bond WJ, Bradstock RA, Pausas JG, Rundel PW (2012) 'Fire in Mediterranean ecosystems: ecology, evolution and management.' (Cambridge University Press: New York)

Lamont BB, Downes KS (2011) Fire-stimulated flowering among resprouters and geophytes in Australia and South Africa. Plant Ecology 212, 2111-2125. doi:10.1007/S11258-011-9987-Y

Lamont BB, Le Maitre DC, Cowling RM, Enright NJ (1991) Canopy seed storage in woody plants. Botanical Review 57, 277-317. doi:10.1007/ BF02858770

Maurin O, Davies TJ, Burrows JE, Daru BH, Yessoufou K, Muasya AM, van der Bank M, Bond WJ (2014) Savanna fire and the origins of the 'underground forests' of Africa. New Phytologist 204, 201-214. doi:10.1111/NPH.12936

Mutch RW (1970) Wildland fires and ecosystems - a hypothesis. Ecology 51, 1046-1051. doi:10.2307/1933631

Pausas JG (2015a) Evolutionary fire ecology: lessons learned from pines. Trends in Plant Science 20, 318-324. doi:10.1016/J.TPLANTS.2015. 03.001

Pausas JG (2015b) Bark thickness and fire regime. Functional Ecology 29, 315-327. doi:10.1111/1365-2435.12372

Pausas JG (2017) Bark thickness and fire regime: another twist. New Phytologist 213, 13-15. doi:10.1111/NPH.14277

Pausas JG, Schwilk D (2012) Fire and plant evolution. New Phytologist 193, 301-303. doi:10.1111/J.1469-8137.2011.04010.X

Pivello VR, Coutinho LM (1992) Transfer of macro-nutrients to the atmosphere during experimental burnings in an open cerrado (Brazilian savanna). Journal of Tropical Ecology 8, 487-497. doi:10.1017/ S0266467400006829 
Ramos DM, Liaffa ABS, Diniz P, Munhoz CBR, Ooi MKJ, Borghetti F, Valls JFM (2016) Seed tolerance to heating is better predicted by seed dormancy than by habitat type in neotropical savanna grasses. International Journal of Wildland Fire 25, 1273-1280. doi:10.1071/ WF16085

Raven PH, Axelrod DI (1978) 'Origin and relationships of the California flora.' (University of California Press: Berkeley, CA)

Ribeiro LC, Pedrosa M, Borghetti F (2013) Heat shock effects on seed germination of five Brazilian savanna species. Plant Biology 15, 152 157. doi:10.1111/J.1438-8677.2012.00604.X
Simon M, Grether R, De Queiroz L, Skema C, Pennington R, Hughes C (2009) Recent assembly of the Cerrado, a neotropical plant diversity hotspot, by in situ evolution of adaptations to fire. Proceedings of the National Academy of Sciences of the United States of America 106, 20359-20364. doi:10.1073/PNAS.0903410106

Warming E (1893) Lagoa Santa: étude de géographie botanique. Revue Générale de Botanique 5, 145-158, 209-233.

Wells PV (1969) The relation between mode of reproduction and extent of speciation in woody genera of the California chaparral. Evolution 23 264-267. doi:10.2307/2406790 